Chapter 14

\title{
PARP Inhibitors in Ovarian Cancer
}

\author{
Jeanine Staples and Annekathryn Goodman \\ Additional information is available at the end of the chapter \\ http://dx.doi.org/10.5772/52888
}

\section{Introduction}

Targeted therapy in cancer has led to intensive searches for the molecular pathways of malignant transformation [1]. In gynecologic malignancies, BRCA 1 and BRCA 2 gene mutations on chromosomes 17 and 13 respectively were identified in the 1990s [2]. Since then, intensive investigation of the pathways for these genes has led to a wealth of information about molecular pathways [3]. The understanding of these molecular pathways has led in turn to the development of novel targeted therapies for women with identified gene mutations [4]. This review reviews the current knowledge of the subset of women with BRCA gene mutations. The characteristics of BRCA deficiency including genetic background and current chemotherapeutic options including mechanisms of resistance are discussed as well. Finally, the data on emerging targeted therapeutic strategies with poly-ADP-ribose-polymerase (PARP) inhibitors and specific PARP clinical trials are reviewed.

\section{BRCA genetic background}

Hereditary Breast and Ovarian Cancer Syndrome (HBOCS) is characterized by a few distinct features: earlier age of cancer onset, higher incidence of bilateral disease, higher incidence of other cancers, and inheritance in an autosomal dominant pattern [5]. A number of genes, as well as associated syndromes, have been implicated in HBOCS, but none more so than the BRCA genes. Individuals with impaired BRCA protein function have a 50-85\% lifetime risk of developing breast cancer and 10-40\% lifetime risk of developing ovarian cancer [6]. Although deleterious mutations in either of the 2 BRCA genes significantly increases one's risk for breast and ovarian cancer, mutations in these genes account for only about $5-10 \%$ of all breast and ovarian cancer cases [7]. Because of genetic testing, the families of the subset of women with BRCA associated cancers can be tested and early intervention is a possibility [8]. These include tamoxifen therapy, bilateral prophylactic oophorectomy, prophylactic 
contralateral mastectomy and combinations of these strategies. Such interventions have been shown to offer substantial life expectancy gain for young women with BRCA associated early stage cancer. Currently, treatment of BRCA-associated breast and/or ovarian cancer is no different than that for the general population. Survival data of BRCA positive patients with ovarian cancer suggests that they have prolonged disease free intervals and overall longer survival than their wild-type counterparts [9].

The Breast Cancer Susceptibility genes (BRCA 1 and 2) are considered tumor suppressors, whose job it is to maintain appropriate cell growth, ultimately by upholding genomic stability [10]. No single unified theory exists regarding the action of the BRCA genes. While disruption of either of the BRCA genes demonstrates similar pathophysiological manifestations, they are indeed unique. They lie on 2 separate chromosomes, each have unique primary sequences, and ultimately carry out their responsibilities via discrete (proposed) mechanisms. Furthermore, their unique mechanisms of action give them distinct characteristics that coincide with distinct risks and prognoses with gene disturbance. Both BRCA genes share a relationship with the gene RAD51, which encodes a protein responsible for assisting in repair of DNA double strand breaks via homologous recombination. When there is a double strand break in the genetic sequence, sequenceX of a specific chromatid, homologous recombination provides a means for the exchange of the same genetic sequence, sequenceX, from the healthy homologous sister chromatid to the damaged one. Rad51 is one of the most important players in HRR. It assists in the search for homology and strand pairing, and its responsibilities are ultimately complemented by the proteins encoded by the 2 BRCA genes [11]. Studies suggest that BRCA2 regulates the intracellular transport and function of RAD51, as well as the enzymatic activity of the RAD51 protein [12]. The relationship between BRCA1 and RAD51 is less clear. There is evidence that BRCA1 physically associates with proteins other than RAD51, creating a complex likely responsible for the creation of resected single-stranded DNA at double strand repair sites [13]. Further data supports BRCA1's role in activation of DNA damage checkpoints. There is also evidence that supports BRCA1's role in altering chromatin structure upon DNA damage to allow easier access for repair.

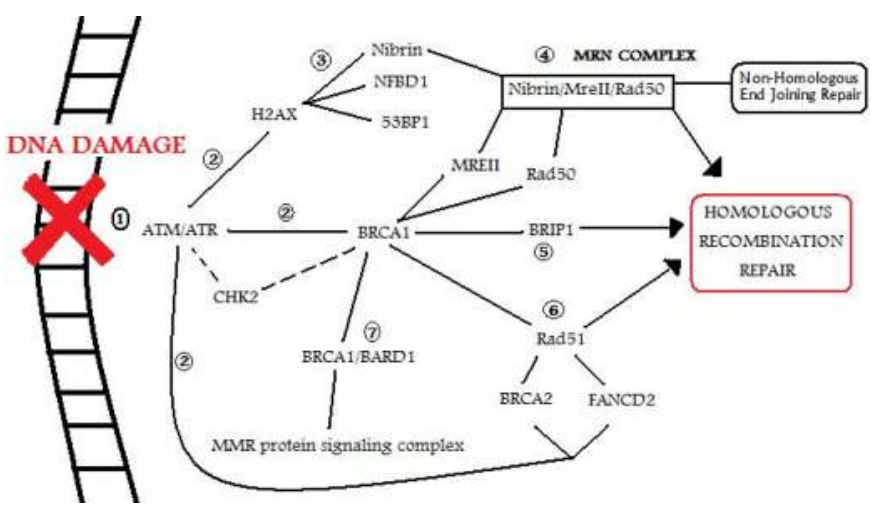

Figure 1. Role of BRCA proteins in Homologous Recombination Repair 
(See Figure 1) 1) DNA damage triggers activation of the ataxia-telangiectasia mutated serine-protein kinase as well as the ataxia-telangiectasia and Rad3 related protein kinase [14]. 2) Once activated, these enzymes phosphorylate and activate a number of intracellular items, including the BRCA1 protein, Checkpoint kinase 2 (which also activates BRCA1), BRCA2, the Fanconi anemia protein complex, H2AX histones involved in forming nuclear foci crucial for DNA repair, and a few others [15]. 3) The H2AX histones co-localize and join with other proteins to form nuclear foci at the sites of DNA damage. These other proteins include a tumor binding protein 53BP1, the nuclear factor with BRCT domains protein 1 NFBD1, checkpoint kinase 2, and Nijmegen breakage syndrome 1 protein Nibrin. 4) Nibrin is part of the MRN complex, which also includes Rad50 and MreII. The MRN complex is important in initial processing of double stranded DNA breaks. It directs the cellular process to continue via homologous recombination or non-homologous end joining. BRCA1 plays a part in regulating the MRN complex by inhibiting MreII [16]. This action depresses the NHEJ pathway and stimulates the Rad51 pathway favoring homologous recombination. 5) BRCA1 also activates BRCA1 interacting protein C-terminal helicase 1 (BRIP1), which unwinds DNA strands near sites of damage allowing other repair machinery to access the damaged sites. The gene that encodes BRIP1 may also act as an oncogene in ovarian cancer. 6) Activation of Rad51 allows it to form a complex with BRCA2 and Fanconi anemia complementation group D2 protein, FANCD2 [17]. This complex is a key player in homologous recombination repair as it is involved in searching for homology as well as strand pairing, while causing Sphase and G2 arrest [18]. 7) Certain homologous recombination repair (HRR) promoting activities of BRCA1 are amplified when it forms a complex with BRCA1 associated RING domain protein 1, BARD1 [19]. This complex may also play a role in mismatch repair via downstream action [20].

\section{Associated breast and ovarian cancer}

Inheritance of a damaging mutation in either BRCA gene can cause disruption of the smoothly regulated replication process of the body's cells, potentially leading to cancer. Though the mechanism is poorly understood, mutations in the BRCA genes show preferential deleterious consequences in breast and ovarian tissues. In the general population, the lifetime prevalence of breast cancer is $12 \%$ and ovarian cancer $1.4 \%$ [21]. A mutation in the BRCA1 gene puts an individual at a 50-85\% lifetime risk of developing breast cancer and a $15-40 \%$ risk of developing ovarian cancer. BRCA2 mutation carriers have a 50-85\% lifetime risk of developing breast cancer and a 10-20\% risk of developing epithelial ovarian cancer. In addition, BRCA mutations are associated with bilateral disease, cancer at a younger age (BRCA1), autosomal dominant inheritance pattern, increased risk of male breast cancer (BRCA2), and increased risk of cancer in other organs [22,23]. Specifically, BRCA positive individuals are at increased risk of epithelial ovarian cancer (EOC), which behaves differently than EOC seen in the general population. Both BRCA1 and 2 carriers have an improved prognosis when compared to their wild-type counterparts. A pooled analysis of 26 observational studies on the survival of women with ovarian cancer, including 1213 EOC cases 
showed that among patients with invasive EOC, having a BRCA mutation was associated with improved 5-year overall survival, with BRCA2 carriers having the best prognosis [9]. See Table 1.

\begin{tabular}{|c|c|c|c|}
\hline & BRCA 1 carriers & BRCA 2 carriers & Non-Carriers \\
\hline Inheritance & Auto-Dominant & Auto-Dominant & Sporadic \\
\hline Prevalence of EOC & $39 \%$ & $22 \%$ & $1.4 \%$ \\
\hline Mean age of onset & 54 & 62 & 63 \\
\hline Tumor: Stage @ surgery & Advanced & Advanced & Advanced \\
\hline Histolology & Serous & Serous & Serous \\
\hline Differentiation & Mod-Poor & Mod-Poor & Mod-poor \\
\hline Treatment & Surgery + Chemo & Surgery + Chemo & Surgery + Chemo \\
\hline Recurrence-Free interval & 14 months & 14 months & 7 months \\
\hline 5-year Survival & $44 \%$ & $52 \%$ & $36 \%$ \\
\hline Other malignancies & $\begin{array}{l}\text { Breast, gastric } \\
\text { hepatobiliary, renal, } \\
\text { testicular, leukemia }\end{array}$ & $\begin{array}{l}\text { Breast (including } \\
\text { higher incidence of } \\
\text { male breast } \\
\text { cancer), prostate, } \\
\text { pancreatic }\end{array}$ & \\
\hline
\end{tabular}

Table 1. Characteristics of BRCA $1 / 2$ associated Epithelial Ovarian Cancer (EOC) $[9,24,25]$

BRCA1 associated breast cancers tend to be of the triple-negative type which is significant because it lacks the 3 biomarkers most commonly implicated in breast cancer, the estrogen and progesterone receptors and the human epidermal growth factor receptor 2 (Her2/neu) [26]. The presence of these biomarkers helps in the guidance of treatment options. Estrogen/ progesterone positive breast cancers are typically treated with hormonal therapy (in conjunction with surgery/radiation), and Her2/neu positive breast cancers are treated with an agent that specifically targets the Her2 receptor, such as Herceptin. When these 3 biomarkers are negative in a newly diagnosed breast cancer, the treatment approach becomes more complicated and prognosisis poor. On the other hand, BRCA2 associated breast cancer is typically hormonal in nature [22]. Current evidence suggests no difference in overall prognosis of breast cancers in BRCA carriers compared to sporadic breast cancers, but BRCA deficiency does appear to be predict chemo-sensitivity [27].

\section{BRCAness}

The term "BRCAness" describes a subset of women with sporadic EOC who display similar phenotypic characteristics to those with a hereditary BRCA mutation [28]. It is widely ac- 
cepted that a deleterious BRCA mutation adversely affects homologous recombination. While the BRCA genes indeed play a very important role in homologous recombination, they are not the only key players. A defect or hiccup in any of the other genes involved in homologous recombination would in theory, affect this process. This describes the notion of BRCAness: Individuals with structurally healthy BRCA genes that are functionally incapable of carrying out homologous recombination due to a defect elsewhere that hinders the entire process. In fact, about 40-50\% of ovarian cancer cases have shown to have some defect in homologous recombination, with a large number of these being associated with BRCA-related defects. See Figure 2.

\section{Molecular Profiling of Serous Ovarian Cancer}

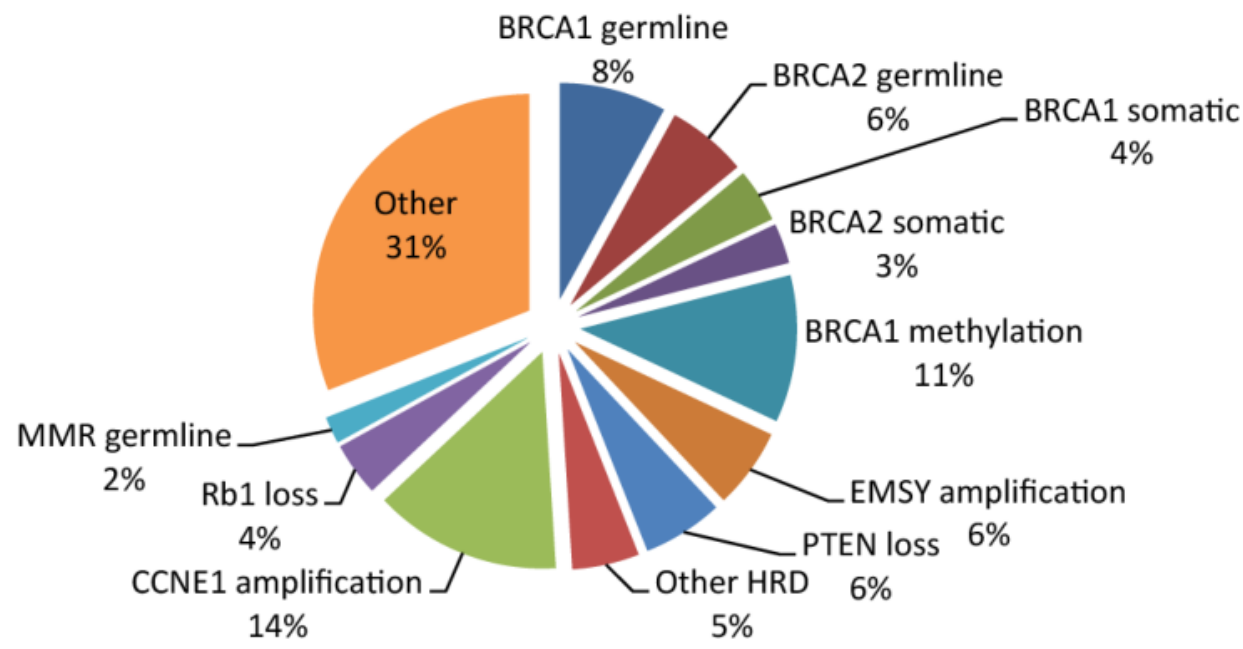

Figure 2. illustrates the molecular profile of serous ovarian cancer. BRCA1 germline, BRCA2 germline, BRCA1 somatic, BRCA2 somatic, BRCA1 hypermethylation, EMSY amplification and PTEN loss have all been shown to lead to impaired homologous recombination, comprising about half of all cases [29]. Sporadic ovarian cancer mutations that affect homologous recombination are clinically significant because they tend to behave like the BRCA cancers. This special sub-group of epithelial ovarian cancer patients show similar therapeutic response and prognosis as their BRCA mutant counterparts which includes improved sensitivity to platinum as well as improved 5 year survival [30]. A few studies have attempted to reveal the mechanism behind BRCAness on a genetic level. There is some data to suggest that transcriptional or post-transcriptional repression of the BRCA1 gene is responsible for such sporadic tumors. For example, hypermethylation of a promotor region upstream from BRCA1 gene that leads to inactivation of BRCA1 protein, causes impaired homologous recombination leading to a sporadic"BRCAness" with an intact yet silenced BRCA1 gene [31].

It should be noted that the specific target of the PARP inhibitor class is not only BRCA mutant cancers; however, it encompasses all that fall under the umbrella of impaired homologous recombination. So in theory, PARP inhibitors should show efficacy in a number of sporadic cancers as well, specifically those that elicit "BRCAness" characteristics [32]. 


\section{Mechanisms of resistance}

Currently, there is no difference in management of EOC between BRCA positive patients and BRCA wild type patients. Maximal surgical cytoreduction, with or without neoadjuvant chemotherapy, is the standard initial approach, excluding individuals who are not good surgical candidates or whose disease precludes optimal cytoreduction [34]. The typical chemotherapeutic regimen is a taxane/platinum based combination therapy. The standard postoperative approach would be 6 cycles (21 days each) of IV paclitaxal with carboplatin [35]

The 5-year survival and prognosis for advanced stage ovarian cancer, in BRCA or wild-type carriers ranges between 10 and 25 percent. Such poor prognosis is due to an incredibly high recurrence rate of advanced ovarian cancer. The extremely high rate of recurrence is due to the development of drug resistance [36]. Initially, 75\% of patients with advanced disease show response to chemotherapy, while the remaining $25 \%$ show intrinsic resistance. However, most of the population with initial chemosensitivity will show relapse within 2 years of initial treatment. Patients who have a shorter interval from their last course of chemotherapy to relapse will show decreased response with future courses [37]. For women who relapse within 6 months of treatment completion, there is a less than $10 \%$ chance of responding to any future therapies. For women whose disease recurs more than 6 to 12 months after initial therapy, chemotherapy includes platinum-based, multi-agent regimens. These women are considered partially platinum sensitive (relapse within 6-12 months) or platinum sensitive (relapse greater than 12 months after initial treatment). For patients who are platinum resistant (relapse within 6 months) or platinum refractory (no initial response), sequential single agents, such as pegylated liposomal doxorubicin hydrochloride or topotecan are suggested [38]. The slightly superior prognosis of BRCA patients compared to sporadic EOC is likely related to their greater sensitivity to platinum based therapy [33]. However, despite initial chemo-sensitivity of BRCA carriers, they will ultimately develop to platinum resistant recurrent ovarian cancer.

PARP Inhibitors are not unlike the standard therapies for ovarian cancer, in that they too have shown evidence of resistance. Theoretically, their maximum potential is seen in cells with impaired homologous recombination. Researchers have hypothesized that resistance to PARP Inhibitors is through DNA repair mechanisms that actually correct the homologous recombination process. Through compensatory mutations, the initial mutational reading frame is corrected to a reading frame that actually produces a wild type BRCA protein [39]. A restoration in BRCA function would further contribute to platinum resistance and create PARP inhibitor resistance. This will need further investigations.

\section{PARP inhibitors}

PARP proteins are involved in a number of cellular processes, including DNA replication, transcriptional regulation, and DNA damage repair [40].Of the numerous PARP proteins detected, PARP1 and PARP2, which are associated with DNA stability, have been intensive- 
ly studied. The PARP enzyme regulates cellular responses to DNA damage, and plays an important role in the repair of single-stranded breaks by excision repair [41]. See Figure 3.

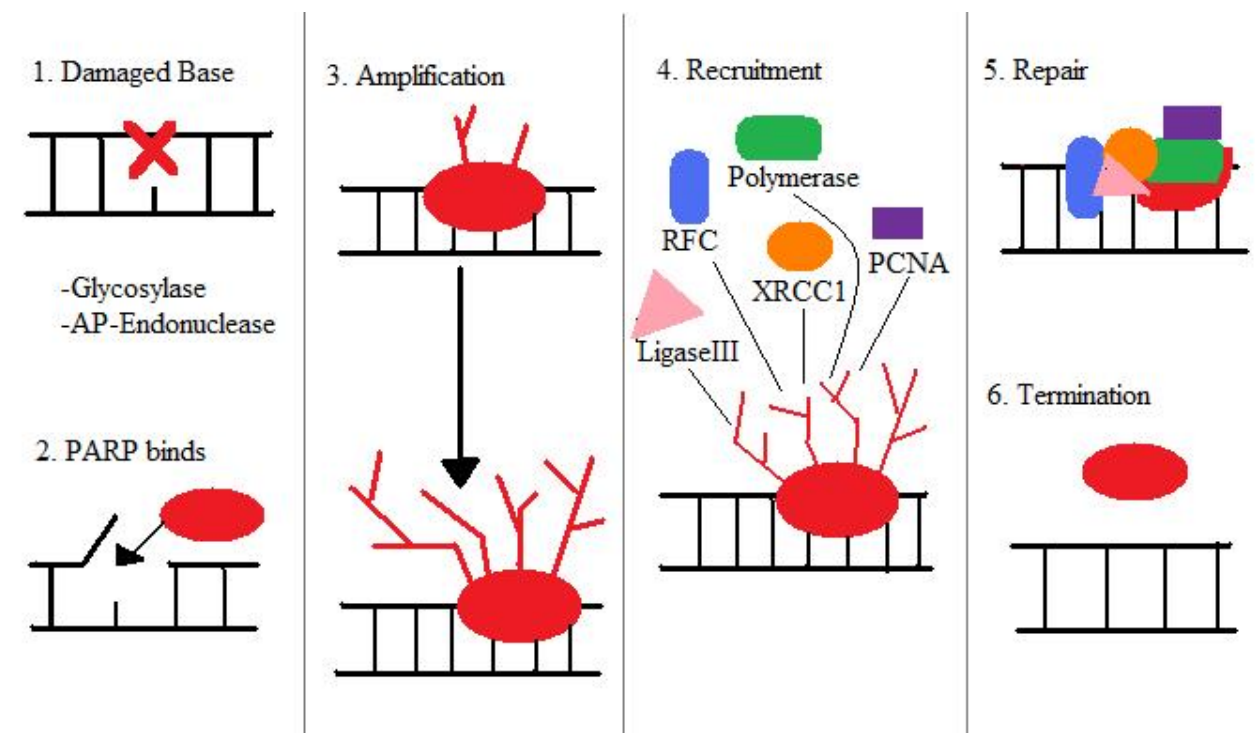

Figure 3. Role of Poly (ADP-ribose) polymerase in Base Excision Repair

The base excision repair (BER) pathway recognizes and removes damaged or inappropriate bases [42]. Damage specific glycosylases recognize the presence of a faulty base and immediately removes it. This leads to the formation of a potentially cytotoxic apurinic or apirimidinic (AP) site. Such sites are then processed by an AP endonuclease, which creates a strand break in the DNA. The enzyme Poly (ADP-ribose) polymerase binds to the strand break and relaxes the chromatin structure to allow for easier access of the BER machinery. Then, PARP transfers ADP-ribose units from NAD+ to nuclear target proteins, histones, and itself. This forms long and branched polymers of poly (ADP-ribose) on the PARP enzyme, that act as a signaling mechanism to recruit the BER machinery, including adaptor factor XECC1, PCNA, RFC, ligase III and DNA polymerase $\beta$. The BER complex assembles at the site of damage and facilitates repair in a coordinated fashion. Once complete, the complex disperses [43].

When PARP is inhibited, common single-strand breaks are converted into double-stranded breaks during DNA replication. In normal wild type cells, homologous recombination is the most common mechanism of repair in these double-stranded breaks which provides a safety net in maintaining genomic stability. In the presence of a deleterious BRCA gene, homologous recombination is impaired. These cells and the tumors that they form have increased susceptibility to PARP inhibition, which leads to decreased chromosomal stability and, ultimately, cell death. See Figure 4. 


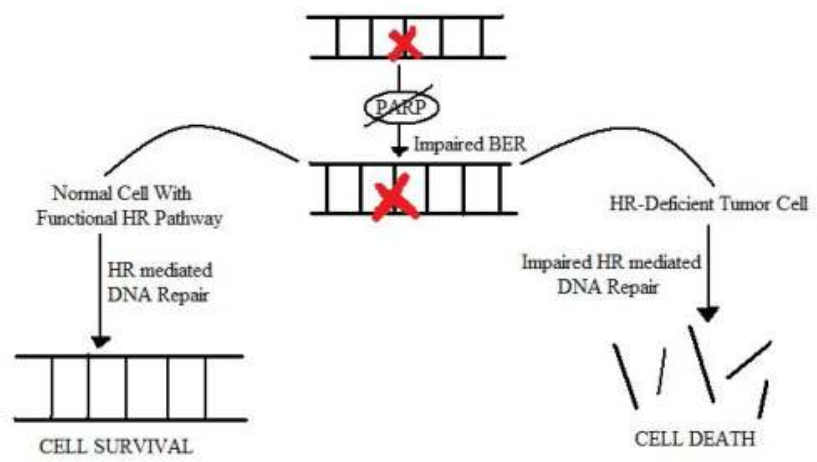

Figure 4. Synthetic Lethality of PARP Inhibition

PARP inhibitors are also hypothesized to increase cytotoxicity of chemotherapeutic agents. Cells treated with chemotherapy, especially platinum based agents, ultimately attain resistance by altering DNA repair processes [44]. It is hypothesized that through PARP inhibition, cells with faulty BRCA function could be prevented from repairing chemotherapy -induced DNA damage $[45,46]$. Clinical trials have examined PARP inhibitors as single agents in patients with impaired homologous recombination, as well as in combination with chemo-radiation therapy.

\section{Clinical trials}

Table 2 shows a list of PARP inhibitors that are currently in clinical development [4]. A full list of studies involving all tumor types can be found through the National Institute of Health website, www.clinicaltrials.gov.

Iniparib is one of the first drugs looked at in the PARP inhibitor class. A phase II trial of inipar$\mathrm{ib}$ in women with advanced ovarian or breast cancer compared the chemotherapeutic regimen carboplatin/gemcitabine with and without iniparib. The iniparib arm showed an improved rate of clinical benefit ( $56 \%$ vs $34 \%, \mathrm{P}=0.01)$, increased rate of overall response $(52 \%$ vs $32 \%, \mathrm{P}=0.02$ ), prolonged median progression free survival ( 5.9 movs $3.6 \mathrm{mo}, \mathrm{P}=0.01$ ), and increased median overall survival (12.3 mo vs $7.7 \mathrm{mo}, \mathrm{P}=0.01$ ) [47]. However, a phase III trial of Iniparib for women with triple negative breast cancer proved to be disappointing $[48,49]$. This trial, which randomized 519 women with triple negative breast cancer to carboplatin with gemcitabine versus carboplatin, gemcitabine plus iniparib demonstrated an increase in progression-free survival among the iniparib arm (5.1 vs 4.1 months, with $\mathrm{P}=0.027$ ), but did not reach statistical significance. Patients were not stratified based on BRCA status, specific triple negative breast cancer subtype, or level of expression of PARP proteins. More recent studies suggest that Iniparib may not actually inhibit the PARP enzyme in vitro. One in particular compared Iniparib to Olaparib and Veliparib [50]. Olaparib and Veliparib proved to inhibit 
formation of the poly-ADP-ribose polymer in intact cells, but Iniparib exhibited little or no ability to inhibit poly(ADP-ribose) polymer formation in situ. Other experiments revealed Iniparib's inability to sensitize cells to cisplatin, gemcitabine and paclitaxel [51]. Iniparib's actual role may be modification of cysteine-containing proteins in tumor cells. If this is in fact the case, failure of the Iniparib phase III trial should not be used to guide further decisions about other PARP inhibitors. Keeping that in mind, Iniparib is continuing to be studied in a number of ovarian cancer trials, some showing promise. A phase II trial examining Iniparib in combination with gemcitabine/carboplatin in patients with platinum-resistant recurrent ovarian cancer has to date shown a $25 \%$ overall response rate consisting of 8 out of 32 confirmed responses [52]. Progression free survival of 6.4 months (95\% CI, 3.0-NE) was demonstrated in an early analysis. The PFS and ORR are significantly improved when compared to a previous study of pegylated liposomal doxorubicin in platinum-resistant recurrent ovarian cancer with an ORR of $11.7 \%$ and mean progression free survival of 3.1 months [53]. Once again, these patients were not stratified based on their BRCA carrier status. A similar study looked at iniparib in combination with gemcitabine/carboplatin in patients with platinum-sensitive recurrent ovarian cancer [54]. This study showed an ORR of $65 \%$, consisting of 26 out of 40 patients, as well as a median progression free survival of 9.5 months. Interestingly, there was no indication of a relationship between BRCA status and response.

\begin{tabular}{|c|c|c|c|}
\hline Agent & $\begin{array}{l}\text { Route of } \\
\text { Administration }\end{array}$ & Trial Interests & Side Effects \\
\hline Iniparib & IV & \multicolumn{2}{|c|}{ Ovarian cancer, uterine carcinosarcoma, NSCLCFatigue, nausea, diarrhea, dizziness } \\
\hline Olaparib & Oral & $\begin{array}{l}\text { Breast and ovarian cancer, the BRCA } \\
\text { population, other advanced solid tumors }\end{array}$ & $\begin{array}{l}\text { Nausea, vomiting, fatigue, taste- } \\
\text { alteration, anorexia }\end{array}$ \\
\hline Veliparib & Oral & $\begin{array}{l}\text { TNBC and BRCA deficient breast and ovarian } \\
\text { cancer }\end{array}$ & Myelosuppression, fatigue \\
\hline Rucaparib & IV & $\begin{array}{l}\text { BRCA associated breast cancer, locally } \\
\text { advanced or metastatic breast cancer, } \\
\text { advanced ovarian cancer }\end{array}$ & Thrombocytopenia and neutropenia \\
\hline INO-1001 & IV & Melanoma, p53 deficient cancer cells & Myelosuppression, transaminitis \\
\hline MK-4827 & Oral & $\begin{array}{l}\text { Advanced solid tumors, ovarian cancer, } \\
\text { hematologic malignancies, advanced } \\
\text { melanoma, advanced glioblastoma }\end{array}$ & $\begin{array}{l}\text { Fatigue, reversible pneumonitis, } \\
\text { myelosuppression, } \\
\text { thrombocytopenia }\end{array}$ \\
\hline AZD-2461 & Oral & Single agent for refractory solid tumors & \\
\hline CEP-9722 & Oral & Single agent for advanced solid tumors & \\
\hline E7016 & Oral & $\begin{array}{l}\text { Advanced solid tumors, melanoma, } \\
\text { glioblastoma }\end{array}$ & \\
\hline BMN-673 & Oral & $\begin{array}{l}\text { Advanced solid tumors and hematologic } \\
\text { malignancies }\end{array}$ & \\
\hline
\end{tabular}

Table 2. PARP Inhibitors in Clinical Development 
Olaparib, on the other hand, is a considered a bona-fide PARP inhibitor and has shown promising results in phase II trials in the treatment of BRCA-deficient advanced ovarian cancer. A recent study looked at oral Olaparib as a single agent, and its effect on BRCA positive vs. BRCA wild-type patients in women with ovarian and breast cancer [55]. Women with advanced high grade serous and/or undifferentiated ovarian carcinoma or triple-negative breast cancer were enrolled and received olaparib $400 \mathrm{mg}$ twice a day. 91 patients were enrolled in this particular study, 65 with ovarian cancer and 26 with breast cancer. 63 of the 65 ovarian cancer cohorts had target lesions and were evaluable for objective response. Among these 63 patients, $41 \%$ of BRCA carriers showed confirmed objective response ( 7 out of 17 with $95 \%$ CI) and a surprising $24 \%$ of BRCA wild-type patients showed confirmed objective response ( 11 of 46 with $95 \%$ CI). The $24 \%$ response of BRCA wild type patients suggests that Olaparib, if not all PARP inhibitors, may provide significant benefit for all patients with ovarian cancer, and not only those with selective BRCA mutation. As mentioned above, around $40-50 \%$ of ovarian cancers, in the absence of a mutation of the BRCA gene, can affect the functional aspect of the BRCA proteins and ultimately homologous recombination. It is for this reason that PARP inhibition likely shows benefit in not just the BRCA mutated population, but a larger population that umbrellas deficient homologous repair. However, for this particular study phase III trials are no longer scheduled to commence because the interim analysis of survival did not show the desired benefit in relation to the benefit in progression free survival. Also, there were no confirmed objective responses reported in the breast cancer patients.

A very similar 2-part study looked at single agent Olaparib, and compared doses (100mg vs. $400 \mathrm{mg}$ ) in the treatment of advanced breast and ovarian cancer in BRCA deficient individuals [56,57]. Among the 57 ovarian cancer patients, the overall response rate of olaparib $100 \mathrm{mg}$ BID was $12.5 \%$ with a clinical benefit rate of $16.7 \%$. For the $400 \mathrm{mg}$ BID arm, ORR was $33 \%$ with a clinical benefit rate of $57.6 \%$. Further stratification showed a response in both platinum-sensitive individuals (38\% ORR) and platinum-resistant individuals $(30 \%)$. Among the 54 breast cancer patients, the overall response of olaparib 100mg BID was $25 \%$ with a progression free survival of 3.8 months. For the $400 \mathrm{mg}$ BID arm, ORR was $42 \%$ with PFS of 5.7 months.

Olaparib is also being looked at as maintenance therapy. A phase II trial studied Olaparib as a maintenance therapy in relapsed serous ovarian cancer. The 265 enrolled patients had received at least 2 previous platinum based chemo regimens with eventual relapse [58]. Early analysis has shown a $65 \%$ reduced risk of progression in the Olaparib arm, improving progression free survival by 3.6 months ( 8.4 mo vs. 4.8). Patients were stratified based on BRCA status, age, race, Jewish ethnicity, prior response to platinum regimen and relapse time, and each subgroup showed an improved progression free survival in the Olaparib arm. Overall survival data has not been analyzed.

Another study looking at differences in response to olaparib based on platinum-response status [59]. This trial looked at oral olaparib as a single agent against advanced ovarian cancer in 50 women with BRCA mutations. Results showed a $61.5 \%$ response rate in platinum- 
sensitive patients, a $41.7 \%$ response rate in platinum-resistant patients and $15.4 \%$ response rate in platinum-refractory patients.

A randomized phase II trial in BRCA deficient advanced ovarian cancer (platinum interval $<12$ months) enrolled 97 women and looked at olaparib dosing, 200mg vs $400 \mathrm{mg}$, and compared its efficacy to pegylated liposomal doxorubicin [60]. Of the 32 low dose olaparib cohorts (200mg BID), $38 \%$ showed objective response with a median progression free survival of 6.5 months. Of the 32 high dose (400mg BID) cohorts, $59 \%$ showed objective response with a median PFS of 8.8 months. These were compared to 33 women who received the standard pegylated liposomal doxorubicin, with an objective response of $38 \%$ and median PFS of 7.1 months, results that were not clinically significant. This study, however, does not necessarily rule out Olaparib's action in BRCA deficient patients. Recent studies suggest that women with BRCA associated ovarian cancer may demonstrate increased sensitivity to Doxil than previously reported in unselected cases [61]. One study in particular showed a 57\% response rate to PLD among BRCA deficient patients, compared to $20 \%$ response rate among those with sporadic EOC. This response was associated with significantly improved progression-free and overall survival. Furthermore, the initial study was actually potentially comparing 2 drugs with particular benefit in BRCA patients and though there is no clinically significant difference among them, they each may show clinical significance when standing alone.

Another PARP inhibitor under investigation is Veliparib. A phase II trial of Veliparib in combination with cyclophosphamide compared to single-agent cyclophosphamide is currently ongoing [62]. This study examines Veliparib's activity against advanced solid tumors and lymphomas. Preliminary results show promising activity in the BRCA subset. Of the 35 patients enrolled, 7 have shown partial response and 6 have stable disease in the veliparib arm. In another study veliparib with or without carboplatin was evaluated in patients with stage III and IV BRCA-associated breast cancer [63]. Of the 22 patients enrolled, only 12 were eligible for evaluation. Complete response was seen in 2 patients and partial response in 6 patients, with a clinical benefit of $75 \%$ seen.

A phase I study showed activity of veliparib and temozolomide in combination against metastatic breast cancer [64]. Of the 41 patients enrolled, complete response was seen in 1 patient, partial response in 2, stable disease in 7 and disease progression in 14. BRCA mutation analysis is currently underway. Another study is currently looking at veliparib in combination with doxorubicin and cyclophosphamide for the treatment of breast cancer and other solid tumors [65]. Of the 18 patients enrolled, 14 have breast cancer (including 5 with BRCA mutations), 3 have ovarian cancer, and 1 other solid tumor. There has been objective anti-tumor activity seen in the BRCA mutation carriers. With this particular regimen, dosing was limited by myelosuppresion. Furthermore, although combination therapy has shown to enhance chemotherapeutic effects, myelosuppression appears to be enhanced as well. More than 50 clinical trials examining Veliparib are currently ongoing, looking at gynecologic cancers, solid tumors, lymphomas, brain tumors, GI and prostate cancer. Most of these are currently recruiting, with only a few in Stage II. It will be very exciting to see the end results of these trials, specifically for our purposes, those involving BRCA analysis. Very few updates have been given, as most of these are in the beginning stages. 


\begin{tabular}{|c|c|c|c|}
\hline Agent & Cancer & Summary & Prelim/Conclusions \\
\hline $\begin{array}{l}\text { Iniparib + } \\
\text { Carbo/Gem } \\
\text { [47] }\end{array}$ & Metastatic TNBC & $\begin{array}{l}\text { Phase } 2 \\
-123 \text { enrolled with advanced } \\
\text { ovarian or breast cancer, } \\
\text { looked at C/G regimen vs. } \\
\text { C/G + Iniparib }\end{array}$ & $\begin{array}{l}\text {-clinical benefit rate of } 56 \% \text { in Iniparib } \\
\text { arm vs. } 34 \% \\
\text {-Increased ORR ( } 52 \% \text { vs } 32 \% \text { ) } \\
\text {-Increased median overall survival } \\
\text { (12.3 mo vs } 7.7 \text { mo) } \\
\text {-Increase in PFS among Iniparib arm } \\
\text { (5.1 vs. } 4.1 \mathrm{mo} \text { ) }\end{array}$ \\
\hline $\begin{array}{l}\text { Iniparib + } \\
\text { Carbo/Gem } \\
{[48,49]}\end{array}$ & Metastatic TNBC & $\begin{array}{l}\text { Phase } 3 \\
-519 \text { enrolled with TNBC and } \\
\text { looked at C/G regimen vs. } \\
\text { C/G + Iniparib }\end{array}$ & $\begin{array}{l}\text {-increased median OS ( } 11.8 \text { vs } 11.1 \\
\text { mo-did not reach clinical significance } \\
\text { *were not stratified on their BRCA } \\
\text { status }\end{array}$ \\
\hline $\begin{array}{l}\text { Iniparib } \\
\text { [50] }\end{array}$ & NA & $\begin{array}{l}\text { Study looked at ability of } \\
\text { Iniparib to inhibit the PARP } \\
\text { enzyme in vitro }\end{array}$ & $\begin{array}{l}\text {-Olaparib and Veliparib proved to } \\
\text { inhibit formation of th epoly } \\
\text {-ADP-ribose polymer in intact cells, but } \\
\text { Iniparib exhibited little or no ability to } \\
\text { inhibit PARP in situ. }\end{array}$ \\
\hline $\begin{array}{l}\text { Iniparib + } \\
\text { Carbo/Gem } \\
{[52]}\end{array}$ & $\begin{array}{l}\text { Platinum resistant } \\
\text { recurrent ovarian } \\
\text { cancer }\end{array}$ & $\begin{array}{l}48 \text { patients with dx of } \\
\text { epithelial ovarian carcinoma, } \\
\text { follopian tube cancer, or } \\
\text { primary peritoneal carcinoma } \\
\text { with platinum-resistant } \\
\text { disease }\end{array}$ & $\begin{array}{l}-25 \% \text { ORR, consisting of } 8 \text { out of } 32 \\
\text { confirmed responses (compare to ORR } \\
\text { of } 11.7 \% \mathrm{~W} / \mathrm{PLD} \text { ) } \\
\text {-PFS of } 6.4 \text { months (compare to PFS of } \\
3.1 \mathrm{mo} \mathrm{w} / \mathrm{PLD} \text { ) }\end{array}$ \\
\hline $\begin{array}{l}\text { Iniparib + C/G } \\
{[54]}\end{array}$ & $\begin{array}{l}\text { Platinum sensitive } \\
\text { recurrent ovarian } \\
\text { cancer }\end{array}$ & $\begin{array}{l}\text { Single arm study } \\
-41 \text { patients with } d x \text { of } \\
\text { recurrent platinum sensitive } \\
\text { ovarian cancer }\end{array}$ & $\begin{array}{l}\text {-ORR } 65 \% \text { ( } 26 \text { out of } 40 \text { patients) } \\
-9.5 \text { mo. median PFS } \\
\text {-no indication of relationship between } \\
\text { BRCA status and objective response }\end{array}$ \\
\hline $\begin{array}{l}\text { Olaparib S.A. } \\
\text { [55] }\end{array}$ & $\begin{array}{l}\text { Ovarian and breast } \\
\text { cancer }\end{array}$ & $\begin{array}{l}91 \text { patients ( } 65 \text { with ovarian } \\
\text { ca, } 26 \text { with breast ca), } \\
\text { stratified based on BRCA } \\
\text { status }\end{array}$ & $\begin{array}{l}-41 \% \text { of BRCA-m ovarian cancer } \\
\text { patients showed COR } \\
-24 \% \text { of BRCA-wt ovarian cancer } \\
\text { patients showed COR -no COR in } \\
\text { breast cancer patients }\end{array}$ \\
\hline $\begin{array}{l}\text { Olaparib S.A. } \\
\text { [59] }\end{array}$ & Ovarian cancer & $\begin{array}{l}50 \text { patients enrolled and } \\
\text { stratified based on response } \\
\text { to platinum }\end{array}$ & $\begin{array}{l}-61.5 \% \text { RR in platinum sensitive } \\
-41.7 \% \text { RR in platinum resistant } \\
-15.4 \% \text { RR in platinum refractory }\end{array}$ \\
\hline $\begin{array}{l}\text { Olaparib S.A. } \\
{[56]}\end{array}$ & $\begin{array}{l}\text { Advanced breast } \\
\text { cancer in BRCA } \\
\text { deficient individuals }\end{array}$ & 54 patients with breast cancer & $\begin{array}{l}\text {-ORR } 42 \% \text { with } 400 \mathrm{mgBID} \text {, PFS } \\
5.7 \text { months -ORR } 25 \% \text { with } 100 \mathrm{mgBID} \text {, } \\
\text { PFS } 3.8 \text { months }\end{array}$ \\
\hline
\end{tabular}




\begin{tabular}{|c|c|c|c|}
\hline Agent & Cancer & Summary & Prelim/Conclusions \\
\hline $\begin{array}{l}\text { Olaparib S.A. } \\
\text { [57] }\end{array}$ & $\begin{array}{l}\text { Advanced ovarian } \\
\text { cancer in BRCA } \\
\text { deficient individuals }\end{array}$ & $\begin{array}{l}57 \text { patients with ovarian } \\
\text { cancer }\end{array}$ & $\begin{array}{l}-12.5 \% \text { ORR of Olaparib } 100 \mathrm{mg} \\
-33 \% \text { ORR of Olaparib } 400 \mathrm{mg} \\
\text {-Response seen in both platinum } \\
\text { sensitive ( } 38 \% \text { ) and platinum resistant } \\
\text { (30\%) disease } \\
\text {-Clinical benefit rate } 57.6 \% \mathrm{w} \\
400 \mathrm{mgBID}, 16.7 \% \text { w } 100 \mathrm{mgBID}\end{array}$ \\
\hline $\begin{array}{l}\text { Olaparib SA } \\
\text { [58] }\end{array}$ & $\begin{array}{l}\text { Relapsed ovarian } \\
\text { cancer, platinum- } \\
\text { sensitive }\end{array}$ & $\begin{array}{l}265 \text { enrolled with at least } 2 \\
\text { previous platinum based } \\
\text { chemo regimens }\end{array}$ & $\begin{array}{l}\text {-improved PFS by } 3.6 \mathrm{mo} \\
-65 \% \text { reduced risk of progression in } \\
\text { Olaparib arm } \\
\text {-no overall survival benefit }\end{array}$ \\
\hline $\begin{array}{l}\text { Olaparib SA vs. } \\
\text { PLD } \\
{[60]}\end{array}$ & $\begin{array}{l}\text { BRCA deficient } \\
\text { advanced ovarian } \\
\text { cancer with platinum } \\
\text { interval }<12 \text { mo. }\end{array}$ & $\begin{array}{l}97 \text { women enrolled, study } \\
\text { compared efficacy/safety of } \\
\text { olaparib vs. PLD }\end{array}$ & $\begin{array}{l}\text {-in olaparib low dose group, 38\% } \\
\text { showed COR, PFS } 6.5 \text { mo } \\
\text {-high dose olaparib group, } 59 \% \text { COR, } \\
\text { PFS } 8.8 \text { mo } \\
\text {-PLD group showed } 38 \% \text { COR, PFS } \\
7.1 \text { mo }\end{array}$ \\
\hline $\begin{array}{l}\text { Veliparib with } \\
\text { Temozolomide } \\
{[64]}\end{array}$ & $\begin{array}{l}\text { Metastatic triple } \\
\text { negative breast } \\
\text { cancer }\end{array}$ & 41 patients & $\begin{array}{l}\text {-complete response in } 1 \text { patient, } \\
\text { partial response in } 2 \text { patients, stable } \\
\text { disease in } 7, \text { progression in } 14\end{array}$ \\
\hline $\begin{array}{l}\text { Veliparib with } \\
\text { Carboplatin } \\
{[63]}\end{array}$ & $\begin{array}{l}\text { Stage IV breast } \\
\text { cancer }\end{array}$ & $\begin{array}{l}22 \text { patients enrolled, } 12 \\
\text { eligible for evaluation }\end{array}$ & $\begin{array}{l}\text {-complete response in } 2 \text { patients, } \\
\text { partial response in } 6 \text { patients } \\
\text {-clinical benefit of } 75 \% \text { seen }\end{array}$ \\
\hline $\begin{array}{l}\text { Veliparib with } \\
\text { Doxo/ } \\
\text { Cyclophospha } \\
\text { mide } \\
{[65]}\end{array}$ & $\begin{array}{l}\text { Breast cancer and } \\
\text { other solid tumors }\end{array}$ & $\begin{array}{l}18 \text { patients enrolled, } 14 \text { with } \\
\text { breast cancer ( } 5 \text { Brca+), } 3 \text { with } \\
\text { ovarian cancer and } 1 \text { other }\end{array}$ & $\begin{array}{l}\text {-objective antitumor activity seen in } \\
\text { brca mutation carriers } \\
-3 / 5 \text { BRCA+ TNBC with partial } \\
\text { response } \\
\text {-stable disease at } 12 \text { weeks in } 8 \text { breast } \\
\text { cancer pt } \\
\text {-MTD } 100 \text { mgBID } \\
\text {-dose limited by myelosuppression }\end{array}$ \\
\hline $\begin{array}{l}\text { Veliparib with } \\
\text { Cyclophospho } \\
\text { mide } \\
{[62]}\end{array}$ & $\begin{array}{l}\text { Refractory solid } \\
\text { tumors and } \\
\text { lymphomas }\end{array}$ & 35 patients & $\begin{array}{l}\text {-combination of Cyclophosphamide/ } \\
\text { veliparib tolerated well } \\
\text {-promising activity in subset of BRCA+ } \\
\text { individuals }\end{array}$ \\
\hline
\end{tabular}

S.A.- single agent; PFS-progression free survival; ORR-overall response rate; COR-confirmed objective response; BRCAWT-wild type; BRCA-m-mutant

Table 3. Clinical Trials [47-65] 
BMN-673 is the newest PARP inhibitor to be developed and is to date the most potent and selective PARP inhibitor. It has been shown to be up to 700-fold more active in vitro in BRCA deficient cell lines when compared to olaparib [66]. Phase I trials have yet to begin. Rucaparib is another new PARP inhibitor being looked into. It is currently the focus of 3 different clinical trials; examining its activity in combination with several different chemotherapeutic regimens, efficacy in BRCA-associated breast cancer, and treatment of patients with locally advanced or metastatic breast and advanced ovarian cancer [4]. There a few other PARP inhibitors that are currently being evaluated for efficacy and tolerability, and will likely acquire more interest in the near future. Table 3 summarizes the findings of the PARP inhibitors discussed above.

Phase I and II trials demonstrated PARP inhibitor's favorable side effect profile; potentially including fatigue, nausea, vomiting, and mood disturbance. Also, myelosuppression has been noted in higher doses, especially when in combination with chemotherapy. These adverse effects are generally mild, especially in comparison with current chemotherapeutic regimens.

\section{Conclusion}

PARP inhibitors have been increasingly studied. This new group of drugs has been shown in multiple phase I and II trials to be efficacious with favorable side effect profiles. The preclinical data which suggested the effect of PARP inhibitors in BRCA deficient cells did not take into account the much larger population of tumors deficient in homologous recombination, with physically healthy yet functionally impaired BRCA genes. This new understanding has further raised the bar for the potential of this new class. PARP inhibitors have been shown to increase progression-free-survival and overall response rate in a number of trials. While there have indeed been some setbacks in the development of these new drugs, some of the major concerns have been addressed. Though Iniparib's phase III trial failure was initially viewed as a major disappointment, later studies proved that Iniparib does not have the same efficacy as its counterparts Olaparib/Veliparib, and ultimately may have no role in PARP inhibition of single-strand break repair. Also, the discovery that Olaparib did not show a clinically significant difference when compared to pegylated liposomal doxorubicin, led to the detection of PLD as a particularly potent agent against BRCA deficient cells. So rather than dismissing Olaparib's effect as not clinically significant, this particular study encouraged further investigation of PLD in this special population. Furthermore, the efficacy of PARP inhibition is evident, but the ideal population that could benefit most from this new class has yet to be determined. Future trials involving PARP inhibitors should undergo extremely strict stratification, as it is crucial to reveal precisely which population stands to benefit. Other concerns that need to be further investigated include mechanisms of resistance, use as frontline vs. maintenance vs. recurrent disease therapy, use in mono-therapy vs. combination with chemo or combination with other targeted therapies. 


\section{Author details}

Jeanine Staples ${ }^{1}$ and Annekathryn Goodman ${ }^{2 *}$

*Address all correspondence to: agoodman@partners.org

1 Boston University School of Medicine, Boston, USA

2 Harvard Medical School, Massachusetts General Hospital, Department of Obstetrics and Gynecology, Boston, USA

\section{References}

[1] Hoeijmakers JH. Genome maintenance mechanisms for preventing cancer. Nature. 2001; 411:366-374

[2] Gayther SA, Warren W, Mazoyer S, Russell PA, Harrington PA, Chiano M, Seal S, Hamoudi R, van Rensburg EJ, Dunning AM, Love R, Evans G, Easton D, Clayton D, Stratton MR, Ponder BA. Germline mutations of the BRCA1 gene in breast and ovarian cancer families provide evidence for a genotype-phenotype correlation. Nat genet, $1995 ; 11: 428-433$.

[3] Venkitaraman, Ashok. Functions of BRCA1 and BRCA2 in the biological response to DNA damage. J Cell Sci 2001; 114: 3591-3598.

[4] Underhill C, Toulmonde M, Bonnefoi H. A review of PARP inhibitors: from bench to bedside. Annals Oncology, 2011; 22(2):268-279.

[5] Daly MB, Axilbund JE, Buys S, Crawford B, Farrell CD, Friedman S, Garber JE, Goorha S, Gruber SB, Hampel H, Kaklamani V, Kohlmann W, Kurian A, Litton J,Marcom PK, Nussbaum R, Offit K, Pal T, Pasche B, Pilarski R, Reiser G, Shannon KM, Smith JR, Swisher E, Weitzel JN; National Comprehensive Cancer Network. Genetic/familial high-risk assessment: breast and ovarian. J Natl Compr Canc Netw 2010; 8:562-594.

[6] King MC, Marks JH, Mandell JB. New York Breast Cancer Study Group. Breast and ovarian cancer risks due to inherited mutations in BRCA1 and BRCA2. Science 2003; 302:643.

[7] Breast Cancer Linkage Consortium. Pathology of familial breast cancer: differences between breast cancers in carriers of BRCA1 or BRCA2 mutations and sporadic cases. Lancet 1997; 349:1505-1510.

[8] Schrag D, Kuntz KM, Garber JE, Weeks JC. Life Expectancy Gains From Cancer Prevention Strategies for Women with Breast Cancer and BRCA1 or BRCA2 Mutations. JAMA, 2000; 283(5):617-24. 
[9] Bolton KL, Chenevix-Trench G, Goh C, Sadetzki S, Ramus SJ, Karlan BY, Lambrechts D, Despierre E, Barrowdale D, McGuffog L, Healey S, Easton DF,Sinilnikova O, Benítez J, García MJ, Neuhausen S, Gail MH, Hartge P, Peock S, Frost D, Evans DG, Eeles R, Godwin AK, Daly MB, Kwong A, Ma ES, Lázaro C,Blanco I, Montagna M, D'Andrea E, Nicoletto MO, Johnatty SE, Kjær SK, Jensen A, Høgdall E, Goode EL, Fridley BL, Loud JT, Greene MH, Mai PL, Chetrit A,Lubin F, Hirsh-Yechezkel G, Glendon G, Andrulis IL, Toland AE, Senter L, Gore ME, Gourley C, Michie CO, Song H, Tyrer J, Whittemore AS, McGuire V, Sieh W,Kristoffersson U, Olsson H, Borg $\AA$, Levine DA, Steele L, Beattie MS, Chan S, Nussbaum RL, Moysich KB, Gross J, Cass I, Walsh C, Li AJ, Leuchter R, Gordon O, Garcia-Closas M, Gayther SA, Chanock SJ, Antoniou AC, Pharoah PD; EMBRACE; kConFab Investigators; Cancer Genome Atlas Research Network. Association between BRCA1 and BRCA2 mutations and survival in women with invasive epithelial ovarian cancer. JAMA. 2012;307(4):382-390.

[10] Yoshida K, Miki Y. Role of BRCA1 and BRCA2 as regulators of DNA repair, transcription, and cell cycle in response to DNA damage. Cancer science 2004; 95(11): 866-871.

[11] Magwood AC, Mundia MM, Baker MD. High levels of wild-type BRCA2 suppress homologous recombination. J Mol Biol. 2012; 421(1):38-53.

[12] Shin DS, Pellegrini L, Daniels DS, Yelent B, Craig L, Bates D, Yu DS, Shivji MK, Hitomi C, Arvai AS, Volkmann N, Tsuruta H, Blundell TL, Venkitaraman AR,Tainer JA. Full-length archaeal Rad51 structure and mutants: mechanisms for RAD51 assembly and control by BRCA2. The EMBO journal 2003; 22(17):4566-4576.

[13] Somasundaram K. Breast cancer gene 1 (BRCA1): role in cell cycle regulation and DNA repair--perhaps through transcription. Journal of cellular biochemistry 2003;88(6):1084-1091.

[14] Cortez D, Wang Y, Qin J, Elledge SJ. Requirement of ATM-dependent phosphorylation of brca1 in the DNA damage response to double-strand breaks. Science 1999; ; 286(5442):1162-1166.

[15] Zhang J, Willers H, Feng Z, Ghosh JC, Kim S, Weaver DT, Chung JH, Powell SN, Xia F. FChk2 phosphorylation of BRCA1 regulates DNA double-strand break repair. Molecular and cellular biology 2004 Jan; 24(2):708-718.

[16] Zhong Q, Boyer TG, Chen PL, Lee WH. Deficient nonhomologous end-joining activity in cell-free extracts from Brca1-null fibroblasts. Cancer research 2002 Jul 15;62(14): 3966-3970.

[17] Taniguchi T, Garcia-Higuera I, Andreassen PR, Gregory RC, Grompe M, D'Andrea AD. S-phase-specific interaction of the Fanconi anemia protein, FANCD2, with BRCA1 and RAD51. Blood 2002 Oct 1;100(7):2414-2420.

[18] Nakanishi K, Yang YG, Pierce AJ, Taniguchi T, Digweed M, D'Andrea AD, Wang ZQ, Jasin M. Human Fanconi anemia monoubiquitination pathway promotes homol- 
ogous DNA repair. Proceedings of the National Academy of Sciences of the United States of America. 2005 Jan 25;102(4):1110-1115 .

[19] Xia Y, Pao GM, Chen HW, Verma IM, Hunter T. Enhancement of BRCA1 E3 ubiquitin ligase activity through direct interaction with the BARD1 protein. The Journal of biological chemistry 2003 Feb 14;278(7):5255-5263.

[20] Chen A, Kleiman FE, Manley JL, Ouchi T, Pan ZQ. Autoubiquitination of the BRCA1*BARD1 RING ubiquitin ligase. The Journal of biological chemistry 2002 Jun 14;277(24):22085-22092.

[21] Stålberg K, Svensson T, Granath F, Kieler H, Tholander B, Lönn S. Evaluation of prevalent and incident ovarian cancer co-morbidity. British Journal Cancer, 2012 May 22;106(11):1860-1865. doi: 10.1038/bjc.2012.164.

[22] Atchley DP, Albarracin CT, Lopez A, Valero V, Amos CI, Gonzalez-Angulo AM, Hortobagyi GN, Arun BK. Clinical and pathological characteristics of patients with BRCA-positive and BRCA-negative breast cancer. J Clin Oncol. 2008; 26:4282-4288

[23] Brekelmans CT, Tilanus-Linthorst MM, Seynaeve C, vd Ouweland A, Menke-Pluymers MB, Bartels CC, Kriege M, van Geel AN, Burger CW, Eggermont AM,MeijersHeijboer H, Klijn JG. Tumor characteristics, survival and prognostic factors of hereditary breast cancer from BRCA2- BRCA1- and non-BRCA1/2 families as compared to sporadic breast cancer cases. Eur J Cancer. 2007; 43(5):867-876.

[24] Chen S, Iversen ES, Friebel T, Finkelstein D, Weber BL, Eisen A, Peterson LE, Schildkraut JM, Isaacs C, Peshkin BN, Corio C, Leondaridis L, Tomlinson G,Dutson D, Kerber R, Amos CI, Strong LC, Berry DA, Euhus DM, Parmigiani G. Characterization of BRCA1 and BRCA2 mutations in a large United States sample. J Clin Oncol 2006 Feb 20; 24(6):863-871.

[25] Boyd J, Sonoda Y, Federici MG, Bogomolniy F, Rhei E, Maresco DL, Saigo PE, Almadrones LA, Barakat RR, Brown CL, Chi DS, Curtin JP, Poynor EA, Hoskins WJ. Clinicopathologic Features of BRCA-Linked and Sporadic Ovarian Cancer. JAMA 2000 May 3; 283(17):2260-2265.

[26] Bauer KR, Brown M, Cress RD, Parise CA, Caggiano V. Descriptive analysis of estrogen receptor (ER)-negative, progesterone receptor (PR)-negative, and HER2-negative invasive breast cancer, the so-called triple-negative phenotype: a population-based study from the California cancer Registry. Cancer 2007 May 1;109(9):1721-1728.

[27] Narod SA. BRCA mutations in the management of breast cancer: the state of the art. Nat Rev Clin Oncol. 2010 Dec; 7(12):702-707.

[28] Turner N, Tutt A, Ashworth A. Hallmarks of 'BRCAness' in sporadic cancers. Nat Rev Cancer 2004; 4: 814-819.

[29] Levine, D. 2011. The Cancer Genome Atlas, Molecular Profiling of Serous Ovarian Cancer. Data retrieved from cBio Cancer Genomics Portal http://www.cbioportal.org/public-portal/ last accessed August 12, 2012. 
[30] Tan DS, Rothermundt C, Thomas K, Bancroft E, Eeles R, Shanley S, Ardern-Jones A, Norman A, Kaye SB, Gore ME. "BRCAness" syndrome in ovarian cancer: a case-control study describing the clinical features and outcome of patients with epithelial ovarian cancer associated with BRCA1 and BRCA2 mutations. J Clin Oncol 2008. Dec 1;26(34):5530-5536.

[31] Russell PA, Pharoah PD, De Foy K, Ramus SJ, Symmonds I, Wilson A, Scott I, Ponder BA, Gayther SA. Frequent loss of BRCA1 mRNA and protein expression in sporadic ovarian cancers. Int J Cancer. 2000; 87:317-321.

[32] McCabe N, Turner NC, Lord CJ, Kluzek K, Bialkowska A, Swift S, Giavara S, O'Connor MJ, Tutt AN, Zdzienicka MZ, Smith GC, Ashworth A. Deficiency in the repair of DNA damage by homologous recombination and sensitivity to poly(ADP-ribose) polymeraseinhibition. Cancer Res 2006; 66: 8109-8115.

[33] Yang D, Khan S, Sun Y, Hess K, Shmulevich I, Sood AK, Zhang W. Association of BRCA1 and BRCA2 mutations with survival, chemotherapy sensitivity, and gene mutator phenotype in patients with ovarian cancer. JAMA. 2011 Oct 12; 306(14): 1557-1565.

[34] Bristow RE, Chi DS. Platinum-based neoadjuvant chemotherapy and interval surgical cytoreduction for advanced ovarian cancer: a meta-analysis. Gynecol Oncol 2006 Dec;103(3):1070-1076.

[35] Bookman MA (2010) the addition of new drugs to standard therapy in the first -line treatment of ovarian cancer Ann Oncol 201021 suppl 7: vii211.Cochrane (2000). Chemotherapy for advanced ovarian cancer (2000). Advanced Ovarian Cancer Trialists Group. Cochrane Database Syst Rev 2000 .

[36] Rabik CA, Dolan ME. Molecular mechanisms of resistance and toxicity associated with platinating agents. CancerTreat Rev 2007; 33:9-23.

[37] Vasey PA. Resistance to chemotherapy in advanced ovarian cancer: mechanisms and current strategies. BrJCancer 2003;89 Suppl 3:S23-8.

[38] Chemotherapy for advanced ovarian cancer (2000). Advanced Ovarian Cancer Trialists Group. Cochrane Database Syst Rev. 2000;(2):CD001418.

[39] Hirschhorn R. In vivo reversion to normal of inherited mutations in humans. J Med Genet. 2003 Oct; $40(10): 721-728$

[40] Stewart DJ. Mechanisms of resistance to cisplatin and carboplatin. Crit Rev Oncol Hematol 2007;63:12-31.

[41] Farmer H, McCabe N, Lord CJ, Tutt AN, Johnson DA, Richardson TB, Santarosa M, Dillon KJ, Hickson I, Knights C, Martin NM, Jackson SP, Smith GC,Ashworth A.Targeting the DNA repair defect in BRCA mutant cells as a therapeutic strategy. Nature. 2005 Apr 14;434(7035):917-21. 
[42] Heitz F, Harter P, Ewald-Riegler N, Papsdorf M, Kommoss S, du Bois A. Poly(ADPribosyl)ation polymerases: mechanism and new target of anticancer therapy. Expert Rev Anticancer Ther. 2010 Jul;10(7):1125-1136.

[43] Ame JC, Splenehauer C, de Murcia G. The PARP superfamily. Bioessays. 2004; 26:882-893.

[44] Fortini P, Dogliotti E. Base damage and single-strand break repair: mechanisms and functional significance of short- and long-patch repair subpathways. DNA Repair 2007 Apr 1;6(4):398-409.

[45] Helleday T, Bryant HE, Schultz N. Poly(ADP-ribose) polymerase (PARP-1) inhomologous recombination and as a target for cancer therapy. Cell Cycle. 2005;4:1176-1178.

[46] Plummer R. Poly(ADP-ribose) polymerase inhibition: a new direction for BRCA and triple-negative breast cancer. Breast Cancer Res. 2011 Aug 16;13(4):218.

[47] Drew Y, Mulligan EA, Vong WT, Thomas HD, Kahn S, Kyle S, Mukhopadhyay A, Los G, Hostomsky Z, Plummer ER, Edmondson RJ, Curtin NJ. Therapeutic potential of poly(ADP-ribose) polymerase inhibitor AG014699 in human cancers with mutated or methylated BRCA1 or BRCA2. J Natl Cancer Inst. 2011 Feb 16;103(4):334-346.

[48] Domagala P, Lubinski J, Domagala W. Iniparib in metastatic triple-negative breast cancer. N Engl J Med. 2011 May 5;364(18):1780-1781.

[49] O'Shaughnessy J, Osborne C, Pippen JE, Yoffe M, Patt D, Rocha C, Koo IC, Sherman BM, Bradley C. Iniparib plus Chemotherapy in Metastatic Triple-Negative Breast Cancer. N Engl J Med 2011 Jan 20;364(3):205-214.

[50] Patel AG, De Lorenzo SB, Flatten KS, Poirier GG, Kaufmann SH. Failure of Iniparib to Inhibit Poly(ADP-Ribose) Polymerase In Vitro. Clin Cancer Res. 2012 Mar 15;18(6): 1655-1662.

[51] Liu X, Shi Y, Maag DX, Palma JP, Patterson MJ, Ellis PA, Surber BW, Ready DB, Soni NB, Ladror US, Xu AJ, Iyer R, Harlan JE, Solomon LR, Donawho CK,Penning TD, Johnson EF, Shoemaker AR. Iniparib nonselectively modifies cysteine-containing proteins in tumor cells and is not a Bona Fide PARP inhibitor. Clin Cancer Res. 2012 Jan 15;18(2):510-523.

[52] Birrer M, Konstantinopoulos P, Penson RT, Roche M, Ambrosio A, Stallings TE, Matulonis U, Bradley CR. A Phase I trial of Iniparib in combination with gemcitabin/ carboplatin in patients with platinum-resistant recurrent ovarian cancer. Presented at 2011 ASCO Annual Meeting. http://www.asco.org/ascov2/Meetings/Abstracts? \&vmview=abst_detail_view\&confID=102\&abstractID=82175 accessed august 12 , 2012.

[53] Strauss HG, Hemsen A, Karbe I, Lautenschlager C, Persing M, Thomssen C. Phase II trial of biweekly pegylated liposomal doxorubicin in recurrent platinum-refractory ovarian and peritoneal cancer. Anticancer Drugs. 2008;19:541-545. 
[54] Penson R, Whalen C, Lasonde B, Krasner CN, Konstantinopoulos P, Stallings TE, Bradley CR, Birrer MJ, Matulonis U. A Phase II trial of Iniparib in combination with gemcitabin/carboplatin in patients with platinum-sensitive recurrent ovarian cancer. Presented at 2011 ASCO Annual Meeting. http://www.asco.org/ascov2/Meetings/ Abstracts?\&vmview=abst_detail_view\&confID=102\&abstractID=82124 accessed August 12, 2012.

[55] Gelmon KA, Tischkowitz M, Mackay H, Swenerton K, Robidoux A, Tonkin K, Hirte H, Huntsman D, Clemons M, Gilks B, Yerushalmi R, Macpherson E,Carmichael J, Oza A. Olaparib in patients with recurrent high-grade serous or poorly differentiated ovarian carcinoma or triple-negative breast cancer: a phase 2, multicentre, open-label, non-randomised study. Lancet Oncol. 2011 Sep; 12 (9): 852-861.

[56] Tutt A, Robson M, Garber JE, Domchek SM, Audeh MW, Weitzel JN, Friedlander M, Arun B, Loman N, Schmutzler RK, Wardley A, Mitchell G, Earl H, Wickens M,Carmichael J.Oral poly(ADP-ribose) polymerase inhibitor olaparib in patients with BRCA1 or BRCA2 mutations and advanced breast cancer: a proof-of-concept trial. Lancet. 2010 Jul 24;376(9737):235-244.

[57] Audeh MW, Carmichael J, Penson RT, Friedlander M, Powell B, Bell-McGuinn KM, Scott C, Weitzel JN, Oaknin A, Loman N, Lu K, Schmutzler RK, Matulonis U,Wickens $\mathrm{M}$, Tutt A. Oral poly(ADP-ribose) polymerase inhibitor olaparib in patients with BRCA1 or BRCA2 mutations and recurrent ovarian cancer: a proof-of-concept trial. Lancet. 2010 Jul 24;376(9737):245-251.

[58] [58]. Ledermann J, Harter P, Gourley C, Friedlander M, Vergote I, Rustin G, Scott C, Meier W, Shapira-Frommer R, Safra T, Matei D, Macpherson E, Watkins C,Carmichael J, Matulonis U. Olaparib maintenance therapy in platinum-sensitive relapsed ovarian cancer. N Engl J Med. 2012 Apr 12;366(15):1382-1392.

[59] Fong PC, Yap TA, Boss DS, Carden CP, Mergui-Roelvink M, Gourley C, De Greve J, Lubinski J, Shanley S, Messiou C, A'Hern R, Tutt A, Ashworth A, Stone J,Carmichael J, Schellens JH, de Bono JS, Kaye SB. Poly(ADP)-ribose polymerase inhibition: frequent durable responses in BRCA carrier ovarian cancer correlating with platinumfree interval. J Clin Oncol. 2010;28:2512-2519.

[60] Kaye SB, Lubinski J, Matulonis U, Ang JE, Gourley C, Karlan BY, Amnon A, BellMcGuinn KM, Chen LM, Friedlander M, Safra T, Vergote I, Wickens M, Lowe ES,Carmichael J, Kaufman B.Phase II, open-label, randomized, multicenter study comparing the efficacy and safety of olaparib, a poly (ADP-ribose) polymerase inhibitor, and pegylated liposomal doxorubicin in patients with BRCA1 or BRCA2 mutations and recurrent ovarian cancer. J Clin Oncol. 2012 Feb 1;30(4):372-379.

[61] Adams SF, Marsh EB, Elmasri W, Halberstadt S, Vandecker S, Sammel MD, Bradbury AR, Daly M, Karlan B, Rubin SC. A high response rate to liposomal doxorubicin is seen among women with BRCA mutations treated for recurrent epithelial ovarian cancer. Gynecol Oncol. 2011 Dec; 123 (3): 486-491 
[62] [62]. Kummar S, Ji J, Morgan R, Lenz HJ, Puhalla SL, Belani CP, Gandara DR, Allen D, Kiesel B, Beumer JH, Newman EM, Rubinstein L, Chen A, Zhang Y, Wang L,Kinders RJ, Parchment RE, Tomaszewski JE, Doroshow JH.A phase I study of veliparib in combination with metronomic cyclophosphamide in adults with refractory solid tumors and lymphomas. Clin Cancer Res. 2012 Mar 15;18(6):1726-1734.

[63] Somlo G, Joseph A. Sparano, Tessa Cigler, et al. ABT-888 (veliparib) in combination with carboplatin in patients with stage IV BRCA-associated breast cancer. A California Cancer Consortium Trial. J Clin Oncol 30, 2012 (suppl; abstr 1010).

[64] Isakoff SJ, B. Overmoyer, N. M. Tung, et al. A phase II trial of the PARP inhibitor veliparib (ABT888) and temozolomide for metastatic breast cancer. J Clin Oncol 28: 15s, 2010 (suppl; abstr 1019)

[65] Tan AR, D. Toppmeyer, M. N. Stein, et al. Phase I trial of veliparib, (ABT-888), a poly(ADP-ribose) polymerase (PARP) inhibitor, in combination with doxorubicin and cyclophosphamide in breast cancer and other solid tumors. J Clin Oncol 29: 2011 (suppl; abstr 3041)

[66] Yugiao Shen, Ying Feng, Bing Wang, et al. Structure and preclinical characterization of BMN 673, a potent and orally active PARP inhibitor as an anticancer agent. Molecular Cancer Therapeutics: Nov 2011; Vol 10, Issue 11, Supplement 1 
